\title{
Fossil invertebrates records in cave sediments and paleoenvironmental assessments - a study of four cave sites from Romanian Carpathians
}

\author{
O. T. Moldovan ${ }^{1,}{ }^{*}$, S. Constantin ${ }^{2, *}$, C. Panaiotu ${ }^{3}$, R. D. Roban ${ }^{3}$, P. Frenzel ${ }^{4}$, and L. Miko ${ }^{5,6}$ \\ 1 "Emil Racovitza” Institute of Speleology, Romanian Academy, Cluj-Napoca, Romania \\ 2"Emil Racovitza" Institute of Speleology, Romanian Academy, Bucharest, Romania \\ ${ }^{3}$ University of Bucuresti, Faculty of Geology and Geophysics, Bucharest, Romania \\ ${ }^{4}$ Institut für Geowissenschaften, Friedrich-Schiller-Universität Jena, Jena, Germany \\ ${ }^{5}$ Faculty of Environmental Sciences, Czech University of Life Sciences, Prague, Czech Republic \\ ${ }^{6}$ Institute for Environmental Studies, Charles University, Prague, Czech Republic \\ *These authors contributed equally to this work.
}

Correspondence to: O. T. Moldovan (oanamol35@gmail.com)

Received: 2 May 2015 - Published in Biogeosciences Discuss.: 15 June 2015

Revised: 8 December 2015 - Accepted: 29 December 2015 - Published: 25 January 2016

\begin{abstract}
Fossil invertebrates from cave sediments have been recently described as a potential new proxy for paleoenvironment and used in cross-correlations with alternate proxy records from cave deposits. Here we present the results of a fossil invertebrates study in four caves from two climatically different regions of the Romanian Carpathians, to complement paleoenvironmental data previously reported. Oribatid mites and ostracods are the most common invertebrates in the studied cave sediments. Some of the identified taxa are new to science, and most of them are indicative for either warm and/or cold stages or dry and/or wetter oscillations. In two caves the fossil invertebrates records indicate rapid climate oscillations during times known for a relatively stable climate. By corroborating the fossil invertebrates' record with the information given by magnetic properties and sediment structures, complementary data on past vegetation, temperatures and hydraulic regimes could be gathered. This paper analyzes the potential of fossil invertebrate records as a paleoenvironmental proxy, potential problems and pitfalls.
\end{abstract}

\section{Introduction}

Karst areas account for only ca. $20 \%$ of the planet's icefree land but they are already known as repositories for welldated, high-resolution paleoclimate and paleoenvironmental proxies such as speleothems (Ford and Williams, 2007). In addition, cave sediments preserve geological, environmental and biological information on the past that may allow paleoenvironmental and paleoclimatic reconstructions (Bosák et al., 1989; Sasowsky and Mylroie, 2004). Clastic sediments transported from the surface through the caves and sometimes intercalated with chemical precipitates are frequently preserved unaltered for millions of years. They provide climate and environmental proxies such as environmental magnetism, sedimentary structures and stratigraphic indicators, and fossil remains and they may be directly or indirectly dated (Bosák et al., 1989, 2003; Sasowsky, 2007; Zupan Hajna et al., 2008). Specific microclimatic features of the cave environments delay the degradation processes of fossil remains (Sasowsky and Mylroie, 2004; Polk et al., 2007; Plotnick et al., 2015). It has been shown (Willerslev et al., 2003; Haouchar et al., 2014; Epure et al., 2014, 2016) that cave sediments provide a buffer environment where even ancient DNA can be preserved under non-frozen conditions. Lack of light, stable environment and oligotrophy are typical for the majority of the subterranean environments (low energy 
caves) and explain the low number of permanent cave inhabitants, the low diversity of microorganisms and the slow biochemical processes. Under optimal conditions, degradation processes may slow down thus ensuring the preservation of fossil remains.

First investigations on fossil invertebrates from cave clastic sediments were undertaken in the Classical Karst of Slovenia (Moldovan et al., 2011). They revealed that Pliocene and/or Pleistocene invertebrate remains can be found in a relatively good state of preservation in cave sediments and that they can be used for the assessment of paleoclimatic and paleoenvironmental conditions of the past $2 \mathrm{Ma}$ or even more. The next step to this approach would be to look into how abrupt climate oscillations of the Quaternary may be reflected in the invertebrate record from caves sediments and what is the potential of this new proxy. With this in mind, we have investigated clastic sequences of four caves from the Carpathian Mountains of Romania in an attempt to develop the use of cave fossil invertebrates and to complete the scarce and fragmentary data on the paleoclimate and paleoenvironment of the region.

From a paleoclimate perspective, the Romanian Carpathians is an interesting region being situated in the transitional zone between the oceanic climates of Western Europe and the arid regions of interior Asia, and connecting the Alpine and the Balkan mountain ranges (Reuther et al., 2007). The paleoenvironmental history of the Carpathians responded to the relative influence of the European continental, Atlantic and Mediterranean synoptic systems, as well as to those of central Asia (Stevens et al., 2011).

Four caves from karst areas in western Romania were investigated for fossil invertebrates (Fig. 1): Pestera Urşilor de la Chişcau (further abbreviated as Ursi), Pestera cu Apă din Valea Leşului (Lesu), Pestera Ciur-Izbuc (Ciur) (northwestern Carpathians), and Pestera Poleva (Poleva, southwestern Carpathians). The topography of all these caves includes a main passage formed by small subterranean streams with fluviatile sediments deposited as underground terraces. All caves are resurgences of sinking streams originating from surface ponors. Sediment samples were taken from the exposed faces, in places marked on Fig. 2. In both regions, the climate broadly reflects a distal influence of the NorthAtlantic Oscillation (NAO) with mild summers and temperate winters. However, in the case of SW Carpathians (Poleva), the current climate is also influenced by the Mediterranean, with more arid summers and warmer winters than in the northwestern regions.

\section{Material and methods}

As a general rule, split sediment samples were taken for the analysis of invertebrates and rock-magnetic properties, respectively. Sediment structures were analyzed in situ, and granulometry analyses were done in the laboratory. The vari- ation of rock-magnetic properties within sediments was used as a proxy for climatic oscillations (Evans and Heller, 2003) with chronological tie-points represented by direct optically stimulated luminescence (OSL) or indirect U-series or radiocarbon dating. We further compared the rock-magnetic record and sedimentological features with the known environment for the biological finds to check if the latter may be used as an independent paleoenvironmental proxy.

\subsection{The caves}

Ursi is a famous repository of fossil remains of cave bears, hyenas and lions especially in its lower, hydrologically active, level (Constantin et al., 2014). It is developed within recrystallized Jurassic limestones from the foothills of Bihor Mountains (NW Romania) at $428 \mathrm{~m}$ a.s.l. The lower level develops along a subterranean stream and includes alluvial terraces atop of which lie cave bear and cave lion remains. Sediment samples were taken at $10 \mathrm{~cm}$ resolution from a $170 \mathrm{~cm}$ long profile (Figs. 1 and 2). The age controls of the profile consists of radiocarbon ages of the fossil remains of a cave lion located atop a matching terrace surface in the vicinity and one OSL dating of the alluvial sediments at ca. $0.75 \mathrm{~m}$ below.

Lesu is located in the Pădurea Craiului Mountains (NW Romania), at ca. $650 \mathrm{~m}$ a.s.l. and it is carved in Jurassic limestones. It is a sub-horizontal stream cave formed along an $800 \mathrm{~m}$ long passage that displays meanders and remnants of alluvial clay-sandy terraces. One profile of $170 \mathrm{~cm}$ in length (Fig. 1) was sampled at a resolution of $10 \mathrm{~cm}$ from an alluvial terrace located at ca. $200 \mathrm{~m}$ from the water emergence (Fig. 2). The age control of the profile consists of one OSL date of the alluvial sediments at ca. $0.6 \mathrm{~m}$ below the surface.

Ciur is also located in the Pădurea Craiului Mountains of NW Romania at $530 \mathrm{~m}$ a.s.l. and it is carved in Triassic limestone along two levels. The upper, hydrologically inactive level has a total length of $650 \mathrm{~m}$ of a phreatic origin. Along the lower, hydrologically active level remnants of alluvial terraces are well preserved. From one such profile, $150 \mathrm{~cm}$ high, located close to the stream emergence (Fig. 2), samples were taken every $10 \mathrm{~cm}$ (Fig. 1). The age control of the profile consists of one OSL dating of the alluvial sediments at ca. $0.4 \mathrm{~m}$ below the surface.

Poleva is located in SW Romania, at ca. $20 \mathrm{~km}$ north of the Danube Gorge ( $390 \mathrm{~m}$ a.s.l.) and was formed in massive Cretaceous reef limestones. The stream in the cave passage currently flows through a small (1-1.5 m deep) canyon incised in rock or older cave sediments. A flowstone sample that grew atop the rocky rim of the canyon and two stalagmites from the alluvial terraces were taken for U-Th dating of the most recent phase of stream entrenching. Sediment samples were collected from a $55 \mathrm{~cm}$ long profile of eroded alluvial deposits from the cut-bank of an abandoned meander of the underground stream (Fig. 2). Here sediments are capped by massive flowstone ca. $25 \mathrm{~cm}$ thick overlaid by thin layers 


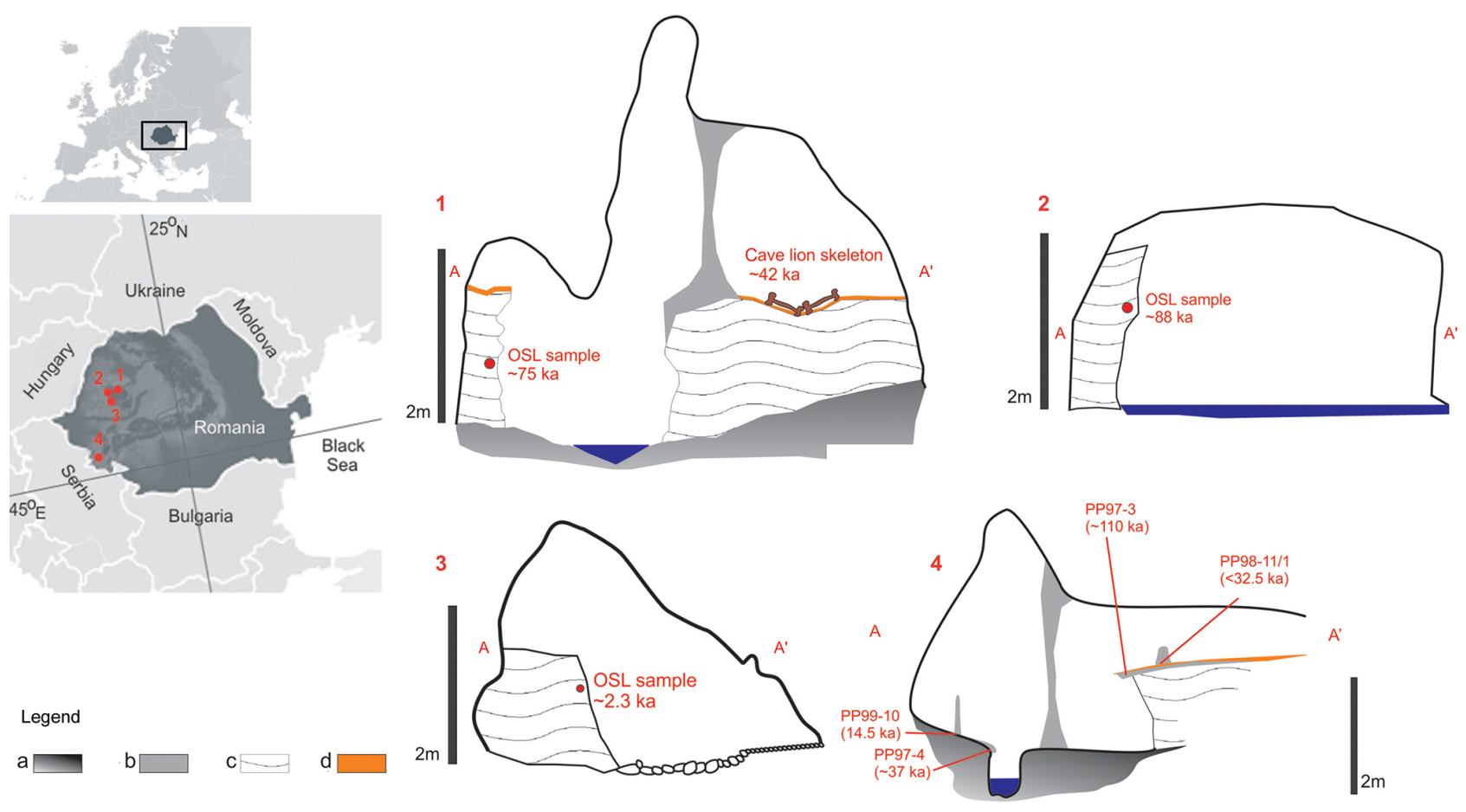

Figure 1. Map of Europe with the location of the studied caves in Romania (left), and the idealized cross-section of the profiles (right). 1. Ursi, 2. Lesu, 3. Ciur, 4. Poleva. Legend: (a) limestone, (b) flowstone and stalagmites, (c) silt sediments, (d) fine, red clay. Note that speleothem dimensions were exaggerated for clarity.

of silty clay on top of which stalagmites have grown (Fig. 1). The sediments were indirectly dated by using the U-Th ages of speleothems from stratigraphically relevant positions.

\subsection{Sampling}

All sediment profiles were chosen so that they do not show any visible depositional hiatuses, therefore we reasonably assume that they accumulated continuously under relatively constant hydraulic conditions during extended time periods of the Late Pleistocene and/or the Holocene.

The sediments from the subterranean terraces were collected along vertical trenches created by removing $\sim 5 \mathrm{~cm}$ of the outer sediment layers, except for Poleva where only a small amount of sediments were available at different depths in the profile. Duplicate sediment samples (typically $0.5 \mathrm{~kg}$ each) were taken for (1) measurements of granulometry, geochemistry and rock-magnetic properties, and (2) screening of invertebrate fossil fauna, respectively.

A total of 59 samples for fossil invertebrates were analyzed. Approximately $1 \mathrm{~kg}$ of sediment was taken from each sampling point and placed in sealed and labeled plastic bags. In the laboratory, the samples were kept in $10 \% \mathrm{KOH}$ for $30 \mathrm{~min}$ and washed successively through sieves of $250 \mu \mathrm{m}$, 125 and $40 \mu \mathrm{m}$ with filtered water. Sub-samples for each sieve dimension were examined separately under an Olympus SZX2 stereomicroscope in $90^{\circ}$ alcohol and each spec- imen was identified under an Olympus BX51 microscope. Identification of the species was carried out following the specific methods for each group.

\subsection{U-Th dating of speleothems}

The U-Th dates reported in this paper were done in the late 1990s by alpha spectrometry method, at that time the most widely used, at the U-series Geochronology Laboratory, Bergen University, Norway. Sub-samples were cut from what seemed to be, optically, the most suitable calcite (columnar or microcrystalline fabrics). The sub-samples were cut as close as possible to the speleothem base and as thin as possible in order to incorporate correspondingly short stratigraphic intervals. However, the low uranium content required quite a large amount of calcite (typically $20-25 \mathrm{~g}$ ); for flowstones sub-samples as thin as $5 \mathrm{~mm}$ could be taken but for stalagmites they usually correspond to ca. $1 \mathrm{~cm}$ axial extension. Analytical procedures for U-Th alpha spectrometric dating are described by Lauritzen and Onac (1999). Detrital ${ }^{230} \mathrm{Th}$ contamination was monitored using the ${ }^{230} \mathrm{Th} /{ }^{232} \mathrm{Th}$ index and corrected using an initial ${ }^{230} \mathrm{Th} /{ }^{232} \mathrm{Th}$ value of 1.5 (Schwarcz, 1986).

Although alpha-spectrometric U-Th dating method is largely considered obsolete nowadays, we consider that the age controls it offers are sufficiently adequate for the purpose of this study. First, the speleothems interbedded within or 

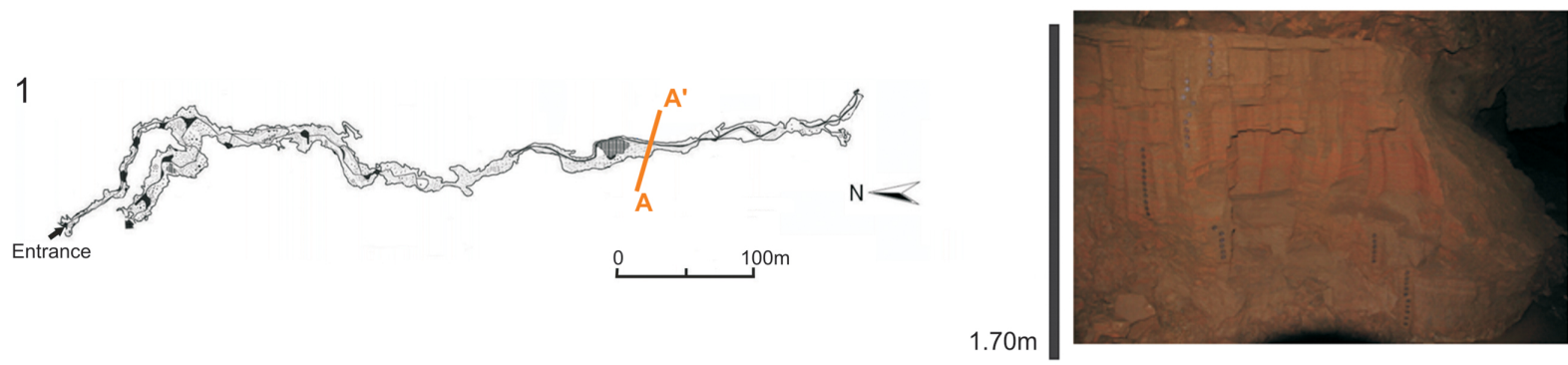

2

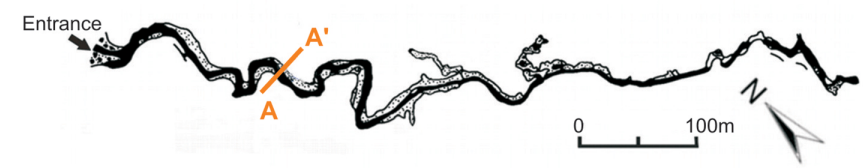

3
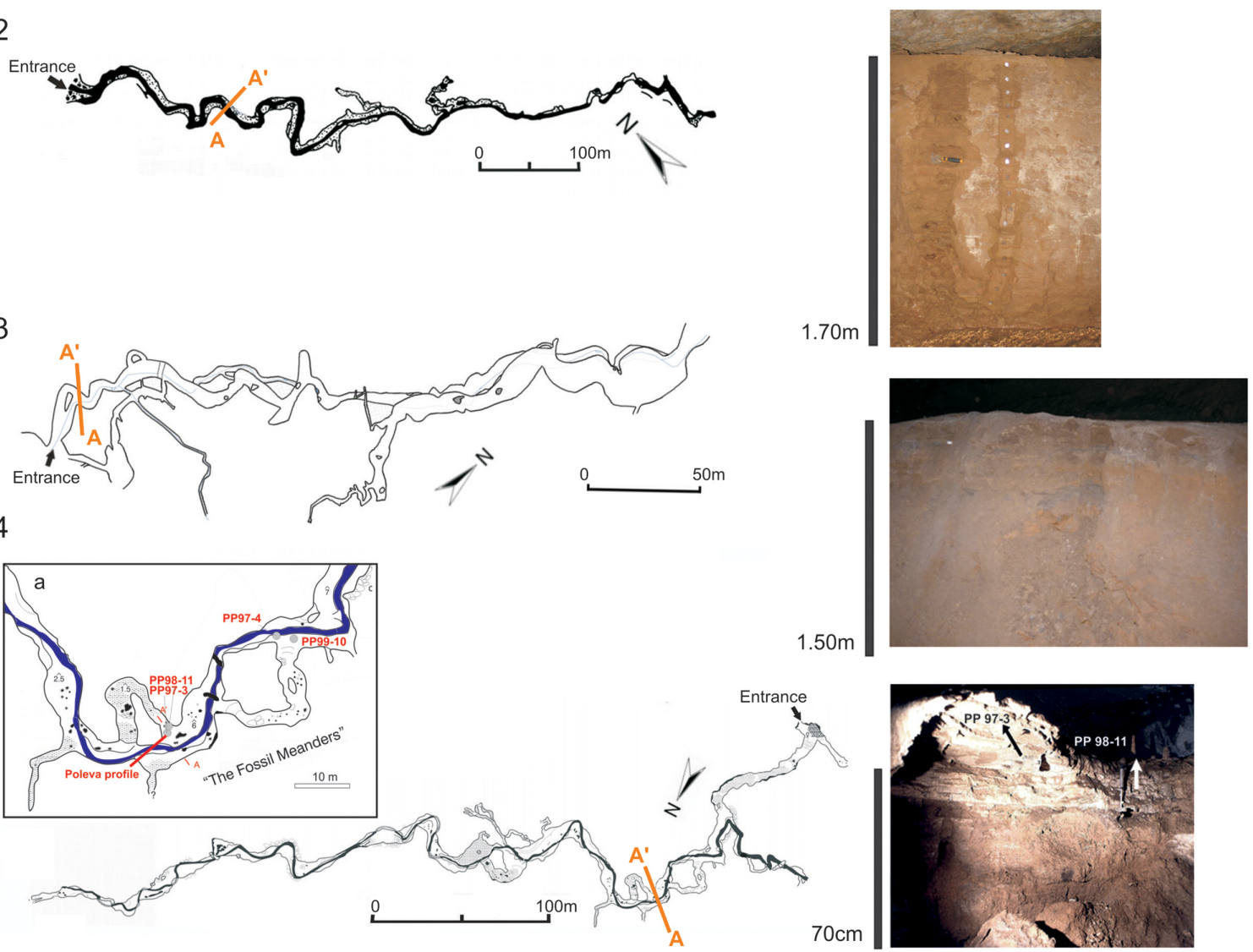

Figure 2. Maps of the selected caves with the location of the sampled profiles (A-A') and their photos. 1. Ursi (modified after Rusu, and Racoviţă, 1981), 2. Lesu (modified after Rusu, 1988), 3. Ciur (modified after Webb et al., 2014), 4. Poleva (modified after Constantin et al., 2007) with the dated speleothem discussed in text (a).

lying on top of alluvial sediment sequences are notoriously "dirty". Alpha spectrometry allows for more robust chemical separation procedures to deal with both detrital ${ }^{230} \mathrm{Th}$ and contaminants such as phosphate that may affect chemical yields and dating reliability. Second, the dates are not used to construct a high-resolution time-series (as for typical speleothem records) but to provide broad chronological controls. Finally, in the absence of organic materials that could be radiocarbon dated (or beyond radiocarbon range), the typical dating uncertainties of $\sim 10 \%$ are comparable or better than those of the OSL dates.

In case of Poleva we have used a combination of several U-Th dates to infer the age of the sediment stack (Ta- ble 1). The age of the sediment is considered to be older than ca. $110 \mathrm{ka}$, which is the age of PP97-3 flowstone (see also Fig. 1). Subsequent flooding in the cave have deposited finer layers of sediments, such as those overlying the PP97-3 flowstone. Their timing is not well constrained but it is believed to be anywhere younger than ca. $32 \mathrm{ka}$ which is the maximum age of stalagmite PP98-11. Other indirect age controls are represented by several U-Th dated stalagmites and flowstone from the matching terraces surfaces in the vicinity of the profile. In a nearby suspended meander, stalagmite PP9810 started to grow at ca. $62 \mathrm{ka}$ being subsequently covered by a clay deposit at some time before ca. $42 \mathrm{ka}$ (Constantin, 2003). A flowstone collected from the rim of the small under- 
ground canyon (PP97-4) yielded a corrected age of ca. 37.7 $( \pm 4.5)$ ka indicating a minimal age for canyon incision. Two stalagmites (PP99-10 and 11) were dated from the terraces at ca. $1.2 \mathrm{~m}$ above the current stream bed and yielded reliable and consistent ages of ca. $15 \mathrm{ka}$.

\subsection{Radiocarbon dating}

The AMS ${ }^{14} \mathrm{C}$ dating of two samples from Ursi were dated at the Oxford Radiocarbon Accelerator Unit (ORAU) and reported by Stuart and Lister (2011).

\subsection{OSL datings}

Sediment samples for OSL datings were collected by hammering $25 \mathrm{~cm}$ long, opaque, plastic tubes $(20 \mathrm{~cm})$ into the sediment sections under no light. Sample preparation for luminescence measurements was performed under lowintensity red light conditions. Only the central portion of the tubes was removed for dating. A 3-day treatment with $10 \%$ $\mathrm{HCl}$ solution was used for carbonates removal, followed by another 3-day $\mathrm{H}_{2} \mathrm{O}_{2}(30 \%)$ treatment for organic matter removal. The coarse grain fractions $(>63-90 \mu \mathrm{m})$ were separated through wet sieving. For the extraction of the finegrained quartz fraction $(4-11 \mu \mathrm{m})$, the particles smaller than $11 \mu \mathrm{m}$ were isolated from the fraction less than $63 \mu \mathrm{m}$ by settling in Atterberg cylinders, according to the Stokes law. This fraction was treated with hexafluorosilicic acid $\left(\mathrm{H}_{2} \mathrm{SiF}_{6}\right)$ for 10 days. Subsequently, the removal of the grains $<4 \mu \mathrm{m}$ was carried out by centrifugation.

For the annual dose determination, radionuclide-specific activities (U-238 / Ra-226, Th-232, K-40) were measured using high-resolution gamma-ray spectrometry, and the dose rates were calculated using the conversion factors tabulated by Adamiec and Aitken (1998). Equivalent dose (De) measurements were undertaken on the standard Ris $\varnothing$ TL/OSLDA-20 reader, equipped with blue LEDs $(470 \pm 30 \mathrm{~nm})$. IR $(875 \pm 80 \mathrm{~nm})$ LEDs were used for infrared stimulation. Blue light stimulated OSL signal was detected through a $7.5 \mathrm{~mm}$ thick Hoya U-340 UV filter. Irradiations were carried out using the incorporated ${ }^{90} \mathrm{Sr}-{ }^{90} \mathrm{Y}$ radioactive source, calibrated against gamma dosed calibration quartz supplied by the Ris $\varnothing$ National Laboratory, Denmark. A dose rate of $0.123 \mathrm{~Gy} \mathrm{~s}^{-1}$ for the fine grains mounted on aluminium disks was obtained at the time of measurement.

The measurement protocol was the Single Aliquot Regeneration (SAR) applied on quartz (Murray and Wintle, 2003; Wintle and Murray, 2006). The OSL dating was done at the Dating and Luminescence Dosimetry Laboratory, BabesBolyai University, Cluj-Napoca, Romania.

\subsection{Grain size analysis}

Grain size measurements on fine samples were performed by treating $\sim 5 \mathrm{~g}$ of the bulk sample, for 14 days, in a plastic box, with $\sim 0.4 \mathrm{~mL}$ of a $1 \%$ solution of $\mathrm{Na}\left(\mathrm{PO}_{3}\right) \mathrm{n}, n \approx 25$
- Graham's salt (Merck). A quantity of $\sim 2.5 \mathrm{~g}$ sample was later extracted from the box and treated again with $\sim 0.2 \mathrm{~mL}$ of $2 \%$ solution of Graham's salt. Each sample was analyzed on a HORIBA Partica LA-950V2 laser scattering particle size distribution analyzer to reveal grain size fractions. The coarser samples were analyzed by vibrating dry sieving of $\sim 100 \mathrm{~g}$ of the bulk sample and weighing the sediment quantity retained on each sieve, on an OHAUS Scout digital balance, down to the $500 \mu \mathrm{m}$ fraction, which was subjected to the same procedure as the fine samples.

Calculations and plots were done using the GRADISTAT 8 software; we applied the method of Folk and Ward (1957), and logarithmic statistics.

The four caves have been sedimentologically analyzed in terms of thickness, grain size and internal structures of depositional units. Grain size analysis was done macroscopically for the fraction $>2 \mathrm{~mm}$ and with a HORIBA laser machine for the fraction $<2 \mathrm{~mm}$. The granulometric scale uses the typical ranges as follows: gravel $>2 \mathrm{~mm}$, sand $(2-0.063 \mathrm{~mm})$, silt $(0.063-0.002 \mathrm{~mm})$ and clay $<0.002 \mathrm{~mm}$. Grain size parameters such as standard deviations and medians were calculated and plotted for environmental interpretations.

\subsection{Rockmagnetism}

For rockmagnetism and paleomagnetism, samples were collected in plastic cylinders $\left(11 \mathrm{~cm}^{3}\right)$ specially designed to avoid the rotation of the sample during the sampling or measurements. The moist sediment allowed us to press the cylinders into the clean face of the outcrop. Sampling interval was between 5 and $10 \mathrm{~cm}$. The cylinders were then excavated, capped and packaged to avoid the loss of humidity during the transport. In the laboratory the samples were kept in a refrigerator between measurements, to preserve the original humidity as much as possible. Additional samples from the same locations were collected in plastic bags for granulometry and the stratigraphy was documented in situ.

In laboratory, the following rockmagnetic measurements were performed for all samples: frequency dependence of magnetic susceptibility, anhysteretic remanent magnetization, isothermal remanent magnetization acquired in a magnetic field of $2 \mathrm{~T}\left(\mathrm{IRM}_{2 \mathrm{~T}} \mathrm{~T}\right)$ and the remaining isothermal remanent magnetization after applying a back field of $0.3 \mathrm{~T}$ $\left(\mathrm{IRM}_{0.3 \mathrm{~T}}\right.$ ). Magnetic susceptibility (mass-specific) was measured using the AGICO MFK1-FA Multi-function Kappabridge at two frequencies of $976 \mathrm{~Hz}$ (low frequency - lf) and $3904 \mathrm{~Hz}$ (high frequency - hf). The corresponding values are referred to $\chi_{\mathrm{lf}}$ and $\chi_{\mathrm{hf}}$, respectively. The frequencydependent susceptibility was $\left(\chi_{\mathrm{fd}}=\left(\chi_{\mathrm{lf}}-\chi_{\mathrm{hf}}\right)\right.$, which is proportional to the concentration of the viscous superparamagnetic (SP) particles (Worm, 1998). Anhysteretic remanent magnetization (ARM) was imparted using an anhysteretic magnetizer AMU-1A (AGICO) coupled with the LDA-3A demagnetizer in an alternating field of $100 \mathrm{mT}$ with a superimposed $50 \mu \mathrm{T}$ bias field, and was then expressed by 
Table 1. Alpha-spectrometry U-series dating results from Poleva; all ratios are activity ratios, and all uncertainties are $1 \sigma$ (only ages in bold were considered in this study).

\begin{tabular}{|c|c|c|c|c|c|c|c|}
\hline Lab. no. & $\begin{array}{l}\text { Sample name/ } \\
\text { position }\end{array}$ & $\begin{array}{l}\text { U conc. } \\
(\mathrm{ppm})\end{array}$ & ${ }^{234} \mathrm{U} /{ }^{238} \mathrm{U}$ & ${ }^{230} \mathrm{Th} /{ }^{234} \mathrm{U}$ & ${ }^{230} \mathrm{Th} /{ }^{232} \mathrm{Th}$ & $\begin{array}{l}\text { Calculated } \\
\text { age (ka) }\end{array}$ & $\begin{array}{l}\text { Corrected } \\
\text { age }(\mathrm{ka})\end{array}$ \\
\hline 1810 & $\begin{array}{l}\text { PP } 97-3 \\
\text { Base } 1.5 \mathrm{~cm}\end{array}$ & $0.102 \pm 0.003$ & $1.26 \pm 0.04$ & $0.70 \pm 0.03$ & 9.2 & $\begin{array}{l}121.9 \\
(+9.14 ;-8.5)\end{array}$ & $\begin{array}{l}109.9 \\
(+9.7 ;-9.1)\end{array}$ \\
\hline 2169 & $\begin{array}{l}\text { PP 98-11/1 } \\
\text { Base } 1 \mathrm{~cm}\end{array}$ & $0.09 \pm 0.003$ & $1.13 \pm 0.05$ & $0.26 \pm 0.02$ & 2.6 & $32.5 \pm 3$ & $<32.5 \pm 3$ \\
\hline 1805 & $\begin{array}{l}\text { PP97-4, } \\
\text { base }\end{array}$ & $0.076 \pm 0.004$ & $1.25 \pm 0.07$ & $0.33 \pm 0.03$ & 11.4 & $\begin{array}{l}42.38 \\
(+4.2 ;-4.1)\end{array}$ & $\begin{array}{l}37.7 \\
(+4.6 ;-4.5)\end{array}$ \\
\hline 2309 & $\begin{array}{l}\text { PP99-11/1 } \\
\text { Base } 1 \mathrm{~cm}\end{array}$ & $0.26 \pm 0.01$ & $1.452 \pm 0.07$ & $0.15 \pm 0.01$ & 13.2 & $17.16 \pm 1.3$ & $15.4 \pm 1.4$ \\
\hline 2348 & $\begin{array}{l}\text { PP99-10 } \\
\text { base }\end{array}$ & $0.035 \pm 0.002$ & $1.05 \pm 0.1$ & $0.13 \pm 0.02$ & $>1000$ & $14.5 \pm 2.9$ & \\
\hline
\end{tabular}

ARM susceptibility ( $\chi$ ARM). The ARM is particularly sensitive to the content of stable single-domain (typically larger than $20-25 \mathrm{~nm}$, but less than $\sim 100 \mathrm{~nm}$ for magnetite) ferrimagnets (Dunlop and Özdemir, 1997). The isothermal remanent magnetizations were imparted using a pulse magnetizer MMPM10 (Magnetic Measurements). Based on these isothermal remanent magnetizations $S$-ratio was calculated for $2 \mathrm{~T}$ magnetizing fields $\left(\mathrm{IRM}_{2} \mathrm{~T}\right)$ and $0.3 \mathrm{~T}$ backfield $\left(\mathrm{IRM}_{0.3 T}\right)$, following the procedures used by Bloemendal et al. (1988) (Eq. 1):

$S=0.5\left(1-\frac{\mathrm{IRM}_{0.3 \mathrm{~T}}}{\mathrm{IRM}_{2 \mathrm{~T}}}\right)$

$S$ values close to 1 show that the dominant presence of low coercivity minerals (magnetite and/or maghemite) and lower values indicate the presence of high coercivity minerals (goethite and/or hematite). All remanent magnetization was measured using JR5 magnetometer. To identify the high coercivity minerals in the presence of more magnetic low coercivity minerals selected specimens from each section were subjected to high field IRM acquisition curves (between 0.3 and $7 \mathrm{~T})$. We applied the protocol of Maher et al. (2004): the specimen packed in caps gel $(\sim 0.6 \mathrm{~g})$ was first magnetized using the MMPM10 pulse magnetizer, then the sample was $\mathrm{AF}$ demagnetized in $100 \mathrm{mT}$ and the remaining remanence was measured.

\section{Results}

\subsection{Age controls}

Although age control is crucial in paleoclimate and/or paleoenvironment interpretation, cave sediments are difficult to date at high-resolution. Our approach was to compare the relative changes in rockmagnetic properties with the faunal ones and use available dating methods to broadly assess the corresponding Pleistocene time periods of their deposition.
In the case of Ursi, the age of the sediments is constrained by a radiocarbon date of a cave lion skeleton on top of the sediment and was assessed to roughly correspond to Marine Isotope Stages (MIS) 3-5c based on one OSL date at a depth of $75 \mathrm{~cm}$. Additional proof for this age was obtained by a combination of OSL dating on correlated terraces and overlying U-Th dating flowstone as shown by Constantin et al. (2014). For Ciur and Lesu, the age of the depositional events were assessed using one OSL dating for each profile, to Late Holocene and MIS 5a-5c, respectively. In Poleva, the sediments are considered to be older than ca. $110 \mathrm{ka}$ and to correspond, most probably to the Eemian. This assumption is sustained by U-Th datings of several other speleothems grown atop correlated terrace sediments from the same cave.

Under these circumstances, the age controls are only rough estimates of the depositional periods. A synthesis of these estimates is presented in Table 2.

\subsection{Sedimentological analysis}

The thickness of sediment stacks varies between $70 \mathrm{~cm}$ for Poleva and 150-170 cm for Ciur, Ursi and Lesu (Figs. 1 and 3). All sediments show parallel lamination (Fig. 3). Both Ursi and Lesu are formed by alternating silts and clays, with Lesu showing several centimeter levels of fine sand in the middle part. The Ciur and Poleva profiles are formed of coarser sediments with fine sand being dominant. The Ciur profile starts with an intercalation of silt and sand showing cross laminations with loose gravel levels at ca. $50 \mathrm{~cm}$ from base. In Poleva, the profile includes medium-sized sand in the first part (ca. $30 \mathrm{~cm}$ ) followed by fine sand towards the top. These are covered by a ca. $5 \mathrm{~cm}$ thick layer of flowstone that marks the end of sediment deposition.

The plot of the clasticity index (C) (the diameter of the bigger clast) with respect to Median (Md) is relevant for the hydrodynamics of the streams and indicates a transport through intermittent suspension (Suspension I) for Ursi, Lesu 


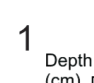

(a)

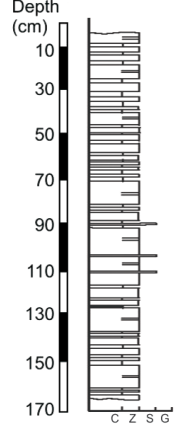

2

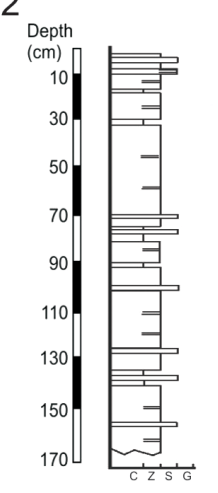

(b)

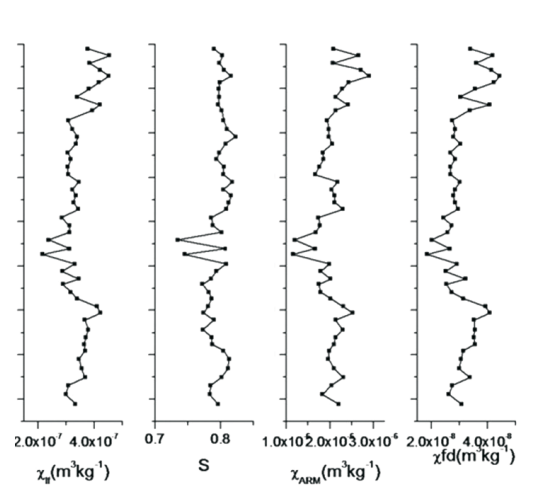

(c)

Number of individuals

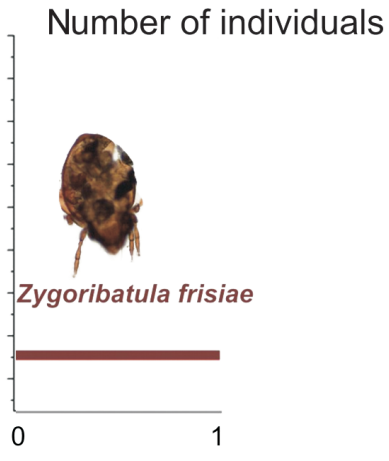

Cavernocypris subterranea
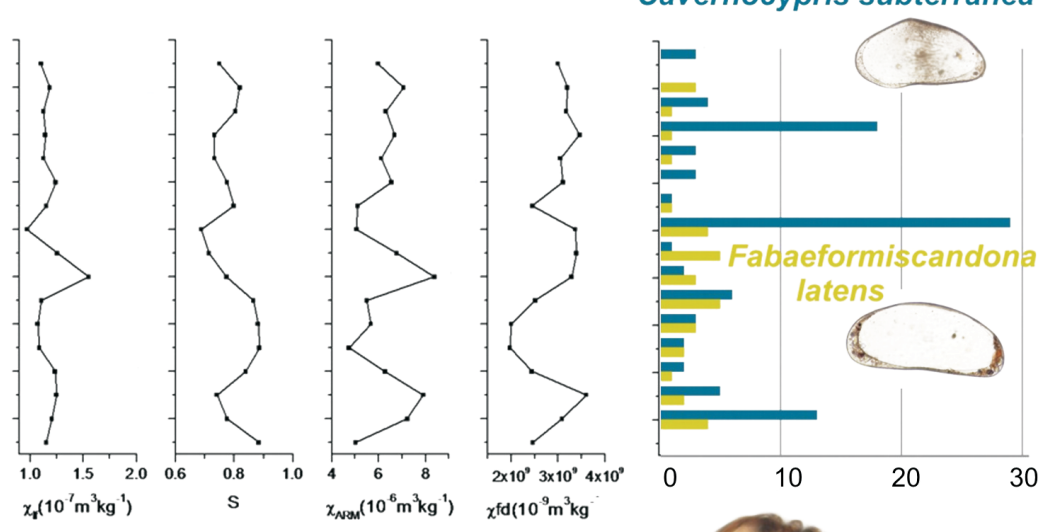

3

3 Depth
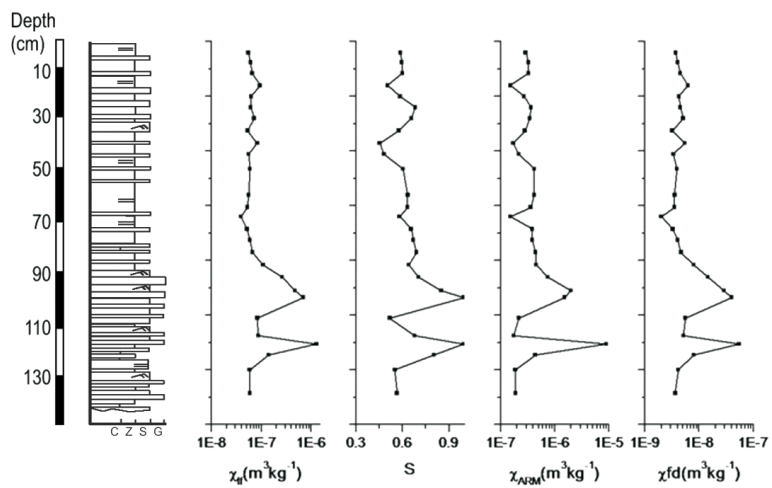

4

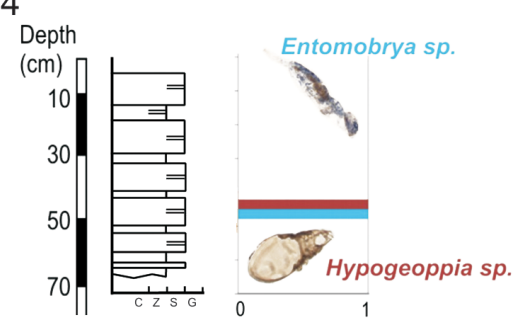

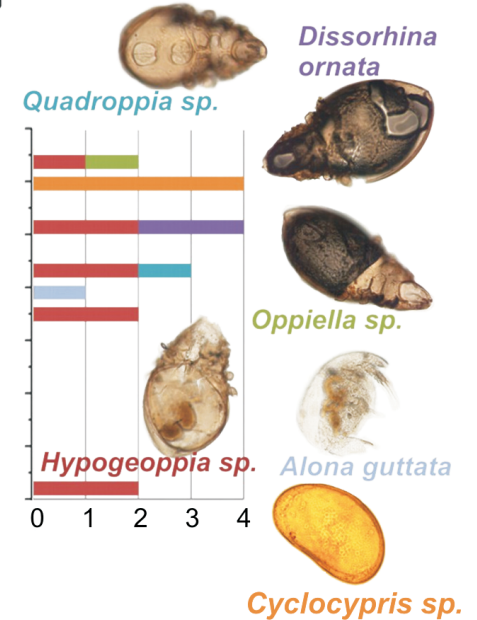

Cyclocypris sp.

Figure 3. Multi-proxy analysis of the profiles in the four studied caves. (a) Granulometry and type of lamination, (b) Rockmagnetic parameters: $\chi$ lf - low frequency magnetic susceptibility, $S$ ratio, $\chi \mathrm{ARM}-$ anhysteretic remanent magnetization susceptibility, $\chi \mathrm{fd}-$ frequency dependence of magnetic susceptibility; ca. variation of the number of identified taxa; 1 . Ursi, 2. Lesu, 3. Ciur, 4. Poleva, $C=$ clay, $Z=$ silt, $S=$ sand, $G=$ gravel. 
Table 2. Age controls of the studied profile in the four Carpathian caves and inferred Marine Isotope Stages (MIS) of their deposition.

\begin{tabular}{lllllll}
\hline Cave & $\begin{array}{l}\text { Depth } \\
(\mathrm{cm})\end{array}$ & $\begin{array}{l}{ }^{14} \mathrm{C} \\
(\mathrm{calkaBP})^{\mathrm{a}}\end{array}$ & $\begin{array}{l}\mathrm{U}-\mathrm{Th} \\
(\mathrm{ka})^{\mathrm{b}}\end{array}$ & $\begin{array}{l}\text { OSL } \\
(\mathrm{ka})\end{array}$ & $\begin{array}{l}\text { Derived age } \\
\text { of sediments } \\
(\mathrm{ka})\end{array}$ & $\begin{array}{l}\text { Inferred climatic } \\
\text { period }\end{array}$ \\
\hline Ursi & 0 & $\begin{array}{l}42.03 \\
( \pm 1.52 ;-0.8)\end{array}$ & & $41-43$ & $\begin{array}{l}\text { MIS 3 to } \\
\text { MIS 5a }\end{array}$ \\
& -75 & & $75.0 \pm 7.2$ & $68-83$ & SubAtlantic \\
\hline Ciur & -50 & & $2.29 \pm 0.26$ & $2-3$ & MIS 5b \\
\hline Lesu & -60 & & $88.1 \pm 12.5$ & $80-111$ & Eemian \\
\hline Poleva & $\begin{array}{l}\text { overlying } \\
\text { flowstone }\end{array}$ & $\begin{array}{l}109.9 \\
-9.1)\end{array}$ & & & & \\
\hline
\end{tabular}

a From Stuart and Lister (2011).

${ }^{\mathrm{b}}$ From Constantin (2003).

and part of Ciur sediments. In the latter case, part of the clasts was also transported by saltation (Fig. 4a).

The plot of the Standard deviation $\left(S_{0}\right)$ versus Median (Md) (Fig. 4b) is indicative for the depositional conditions. The Ursi profile shows a combination of slackwater and backswamp facies, and the terrace sediments were deposited at high water levels from a low-energy stream. In Lesu and especially in Ciur the sediments were deposited from higher energy waters and channel facieses are present. No samples were available for Poleva, but the field observation indicates a channel facies in this case too.

\subsection{Rockmagnetism}

In all measured sediments from the Ursi, Leşu and Ciur the ferromagnetic minerals are a combination of low coercivity minerals (magnetite and/or maghemite) and high coercivity minerals (goethite or hematite) as it is indicated by most of the values of $S$ ratio (Fig. 3). High field isothermal remanent magnetization acquisition curves (between 0.3 and $7 \mathrm{~T}$ ) showed that the high coercivity mineral is hematite in cases of Urşi and Leşu and goethite in Ciur. Despite this complex mineralogy, the oscillations of the magnetic susceptibility are mainly controlled by input of single domain and superparamagnetic grains of low coercivity minerals.

\subsection{Fossil invertebrates in cave sediments}

The following terrestrial and aquatic fauna groups were identified in the sediments of the four studied caves: Bivalvia, Gastropoda, Nematoda, Ostracoda, Cladocera, Oribatida and Insecta (mainly Collembola) (Fig. 5). All taxa were introduced into the caves together with surface sediments. They are in relatively good state of preservation allowing their identification at species or genus level for most of the specimens (Fig. 6).

There were differences between caves both in number of fauna groups and dominant groups. In Ursi and Poleva the number of both groups and individuals was very low, while in the other two caves the number of groups (6 in Ciur) and individuals (131 ostracod valves in Lesu) was higher. Most of the identified species belong to oribatid mites (Acarina, Oribatida) and ostracods.

One individual of Zygoribatula frisiae (Oudemans, 1916) was identified in Ursi, near the base of the profile (Fig. 3). In Ciur, oribatid mites were constantly present along the profile, even though in small numbers (Fig. 3). The mites were found only in the silt levels deposited under slow energy flow or stagnant water episodes. One individual belonging to Oppiella (Jacot, 1937) was identified in the sediments of Ciur, together with representatives of Hypogeoppia Subias, 1981, Quadroppia Jacot, 1939 and Dissorhina ornata (Oudemans, 1900). Hypogeoppia was found in several layers. This is a new species close to Hypogeoppia belgicae Wauthy and Ducarme, 2006 described from Belgian caves. The identified Quadroppia, similar to Q. quadricarinata (Michael, 1885), is a Holarctic distributed genus. One Hypogeoppia sp. and one collembolan Entomobrya sp. Rondani, 1861 were identified in Poleva sediments (Fig. 3).

Aquatic representatives were identified in Ciur and Lesu. In Ciur, there were two layers containing only aquatic representatives. At $-30 \mathrm{~cm}$ four individuals of the ostracod $C y$ clocypris sp. Brady and Norman, 1889 and at $-60 \mathrm{~cm}$ one individual of the cladoceran Alona guttata G.O. Sars, 1862 were found. Lesu was dominated by the ostracods, Cavernocypris subterranea (Wolf, 1920) and Fabaeformiscandona latens (Klie, 1940) (Fig. 5). None of these two species was identified in present-day cave fauna. Most ostracods were single valves, with only 13 entire individuals (Fig. 7). The ratio of $89.3 \%$ between juvenile and adults is high (Fig. 7).

\section{Discussion}

Direct dating of invertebrate fauna from cave sediments is impossible due to its smallness and scarcity. On the other 
(a)

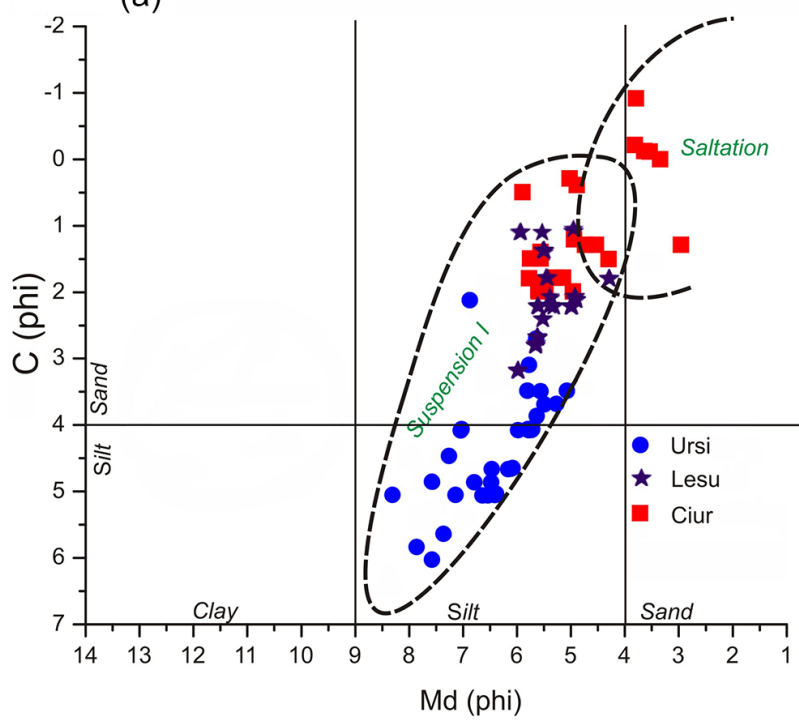

(b)

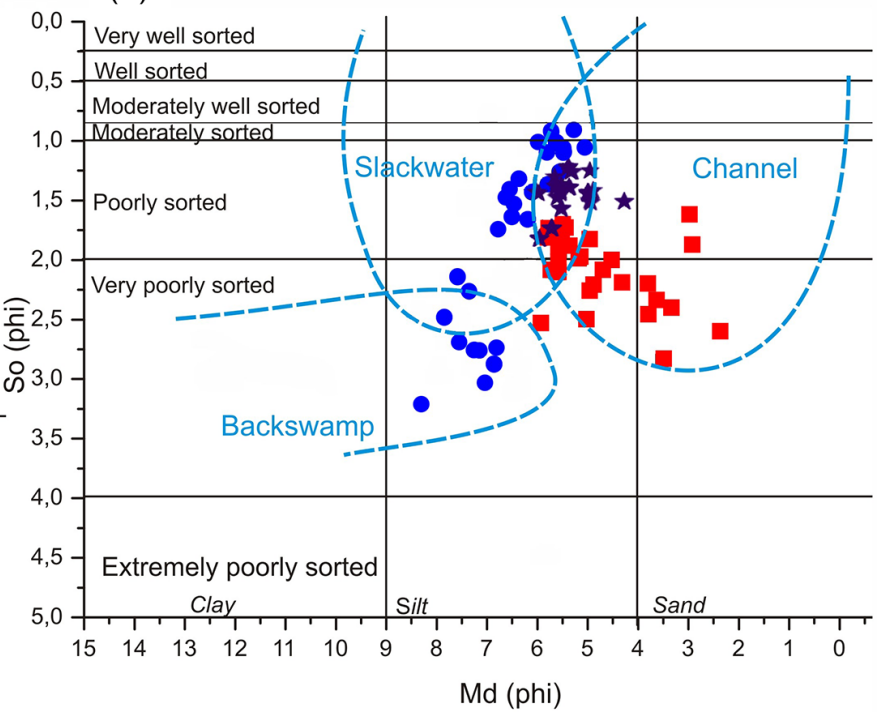

Figure 4. The plotting Median (Md) vs clasticity index (C) (a) and the plotting of median (Md) vs. standard deviation (So) (b) of the fraction finer than $2 \mathrm{~mm}$, from the Ursi, Ciur and Lesu. Grain size is in phi units [- $\log _{2}$ (dimension in mm)]. The data are grouped and suggest the transport and accumulations processes, typical for the fluidal, unidirectional flows, as saltation and suspension; the channel, slackwater and backswamp facies were recognized.
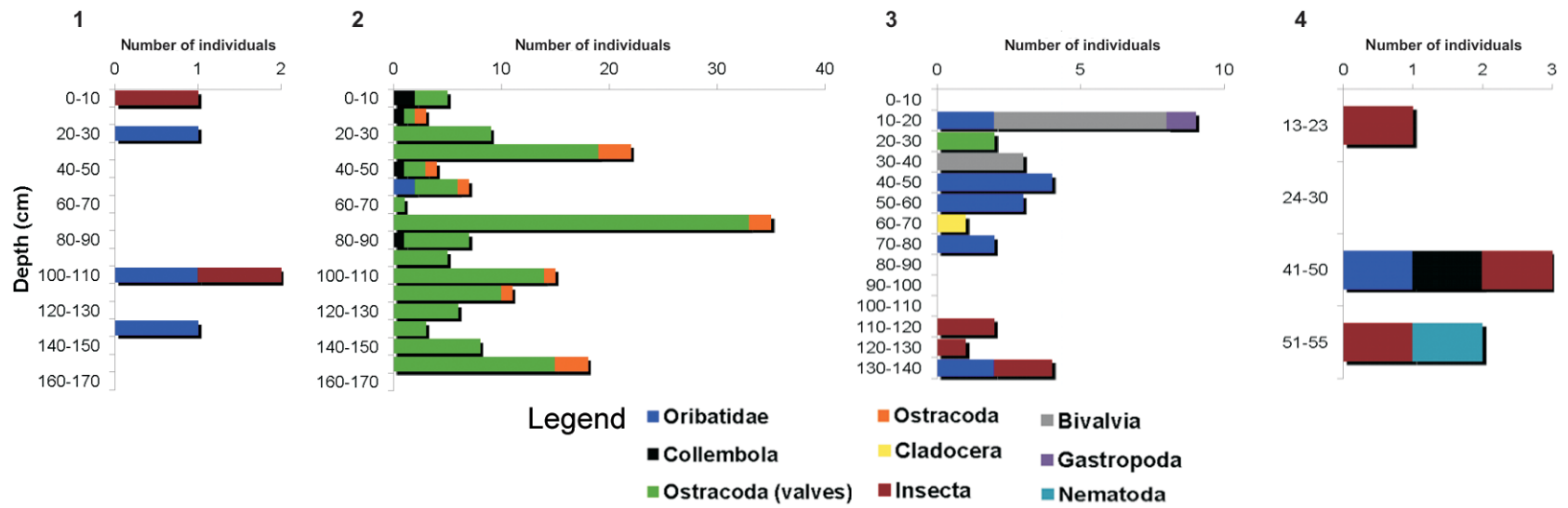

Figure 5. Identified fossil invertebrate groups from cave sediments of the Carpathian region: 1. Ursi, 2. Lesu, 3. Ciur, 4. Poleva.

hand, there are only a few absolute dating methods that may be applied to such sediments, such as OSL, radiocarbon (for fossil remains), or U-Th (for speleothems), each having their limitations. One method that may be routinely used in order to generate records that may be interpreted paleoclimatically is the measurement of rockmagnetic properties of sediments.

Recent soil and paleosols from the loess deposits in surrounding areas of the Carpathians Mountains have shown a strong enhancement of the magnetic susceptibility due to the production of superparamagnetic and single domain magnetite and/or maghemite during pedogenesis (e.g. Necula et al., 2013; Buggle et al., 2014). Taking this into account we interpret that the presence of superparamagnetic grains indicates the transport of soils in the studied caves by under- ground rivers (Ellwood et al., 2001). The frequency dependence and the amplitude of magnetic susceptibility suggest stronger pedogenesis outside the cave for Ursi and Ciur than in the case of Leşu. This is consistent with the MIS 5b age tentatively assigned to the Lesu profile, and with our interpretation of the paleoenvironmental conditions as derived from the faunal spectra in this cave (see below).

Zygoribatula frisiae found in Ursi is living today in more arid settings (Shepherd et al., 2002). This mite is xerotolerant, living in drying-out mosses and lichens and often in arboricole microhabitats. The presence of the xero-tolerant $Z$. frisiae at $-140 \mathrm{~cm}$ in the studied profile is indicative for the deposition of the sediments in one of the MIS5 inter-stadials, at least for the lower part of the profile (Fig. 8). This is further 


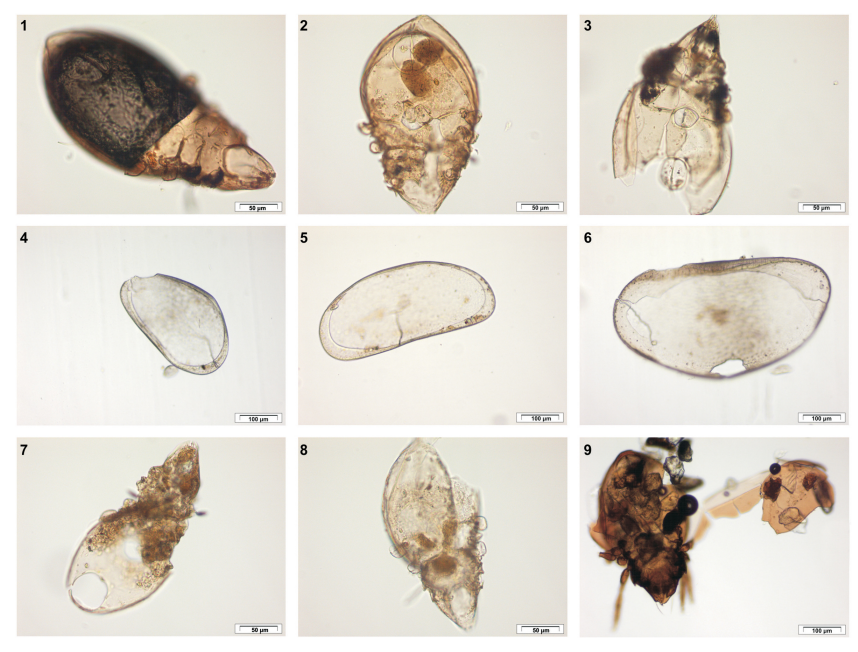

Figure 6. Some examples of fossil invertebrates in different states of preservation found in Ciur ( Oribatida; 1-3), Les ( Ostracoda; 4-6), Poleva (Oribatida; 7-8) and Ursi ( Oribatida; 9).

supported by the backswamp-type depositional facies that include silts and laminated clays pointing towards a deposition during a climatic optimum (Constantin et al., 2014), and explained by the strong pedogenesis outside the cave also apparent in the magnetic susceptibility profile.

Hypogeoppia representatives are present at different levels in the Ciur sediment profile (at $-20,-40,-50,-70$, and $-140 \mathrm{~cm}$ ), alone or in association with Quadroppia sp. This last taxon is indicative for a forest habitat (Seniczak et al., 2006) above the cave, while Hypogeoppia species are euedaphic found in moist nutrient-poor soils of grasslands and forests (Subías and Rodríguez, 1987; Siepel and Dimmers, 2010) but also in extant cave fauna (Wauthy and Ducarme, 2006). Oppiella sp. is a common genus with broad range, including both more specialized species as well as euryoecous ones, so the interpretation remains difficult. The other taxon, Dissorhina ornata, that appear together with Oppiella sp. only in the upper part of the profile is also broadly distributed, but abundant in more open habitats, which might be associated with the flooding events during that time period and may explain the changes of species from one level to another. Flooding events in the upper part of the profile are also supported by the presence of Cyclocypris sp. that appears in a single level with gravels at $-30 \mathrm{~cm}$ and could correspond to a rapid change of vegetation on the surface. Dissorhina ornata is found at the border between forest and open areas (Seniczak et al., 2006) and species of the genus Opiella (sensu lato) can be considered one of the most common arthropod groups on Earth (Norton and Palmer, 1991), with high diversity and abundance in forest litter, also present in shrublands, ecotone zones and grasslands. Some authors (Lotter et al., 1997; Taylor and Wolters, 2005) mentioned the tolerance of the genus Dissorhina to drought. Alona guttata found in the middle part of the profile $(-60 \mathrm{~cm})$ is generally associated with benthic, warmer conditions, with increasing density of vegetation and more acidic waters (Szeroczyñska and Sarmaja-Korjonen, 2007; Nováková et al., 2013). The profile includes different communities indicating different environmental conditions at surface. The Hypogeoppia sp. from the lowest part of the sediments indicate the presence of moist forested and/or grassland areas. The middle part of the sediment layers suggests a warm climate, while the upper part is indicative for a mixture of open and forested habitats.

The middle to low part of the profile in Ciur is associated with coarser sediments indicating a high-energy hydraulic regime and frequent flooding episodes. Within the middle and upper parts of the profile, the low values of magnetic susceptibility and minor frequency dependence suggest that the soils were not significantly eroded and transported in the cave. The estimated age (Late Holocene) explains the strong pedogenesis suggested by magnetic measurements. Pollen data in the region (Feurdean et al., 2013) document the onset of a rise in diversity and large-scale forest clearance (with $\mathrm{Fa}$ gus sylvatica and Abies alba recording the greatest decline), burning, pastoral activities and arable farming at lower elevation in the same period. The invertebrates in Ciur are documenting fast changes and alternation of forest and more open habitats at the surface. The magnetic susceptibility variations do not support the hypothesis of significant changes in temperature; however, the changes in fossil invertebrates fauna suggest that vegetation changed at $\sim 2000$ years ago. The sudden changes in fauna communities and the massive input of sediments may be due to flooding during the Subatlantic, a period characterized by a climatic cooling and rainfall increase.

The aquatic species in Lesu are different in their ecological requirements and indicate the deposition of sediments in a broadly cold period, with variations towards even lower temperatures when Cavernocypris subterranea was dominant. C. subterranea prefers springs and is coldstenothermal, polyrheophilic, polytitanophilic, stygophilic, while Fabaeformiscandona latens prefers groundwater and is oligothermophilic, mesorheophilic, oligotitanophilic, stygobitic (Meisch, 2000). The presence of only a few entire individuals and the high juveniles/adults ratio suggest that the species were not typical cave dwellers but they were transported from surface. We estimated that sediments were deposited during the MIS 5b (Fig. 8). This was a period of significant changes in climate, including northward expansion of grassland and dry shrubland in Eurasia (Herold et al., 2012). The low values of both magnetic susceptibility and its frequency dependence come into agreement with the deposition of sediments during a cold period when the pedogenesis was probably less intense outside the cave.

The identified fossil invertebrates in Poleva belong to soil or grassland and/or forest litter fauna and their ecology indicate an above-cave environment dominated by moist deciduous forest. The Hypogeoppia species that was found in this cave is the same as the one found in Ciur, suggesting that the 


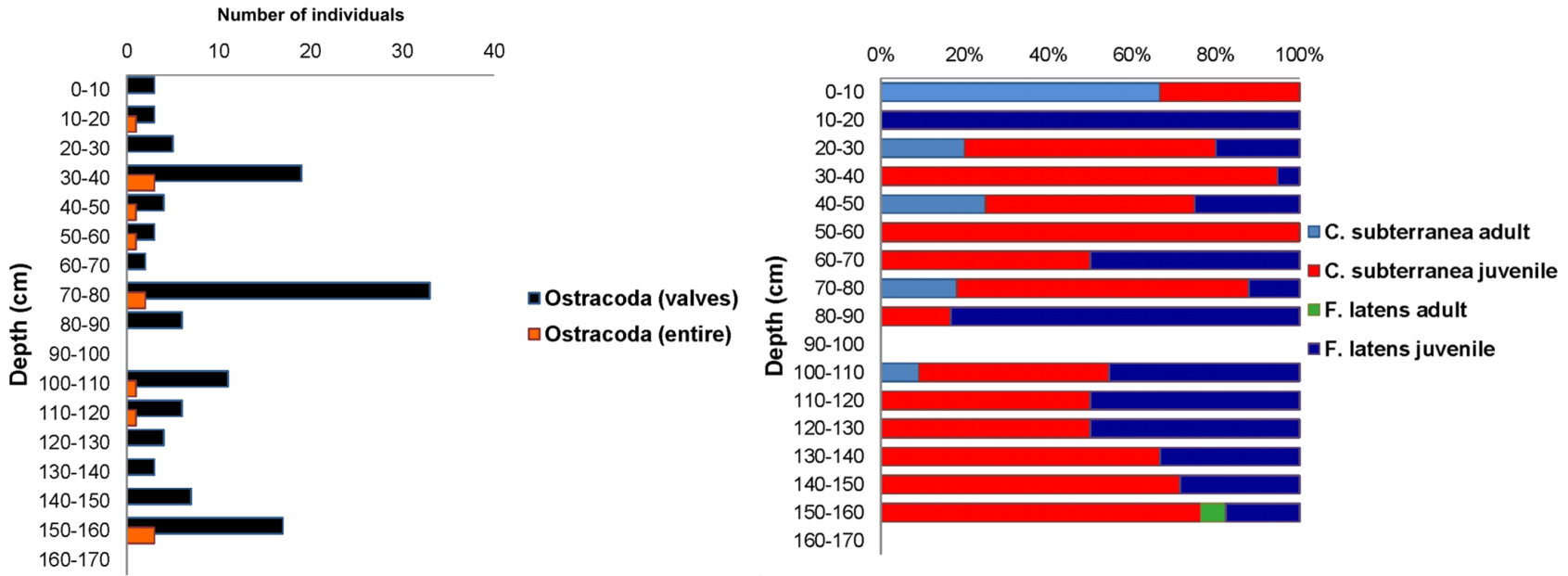

Figure 7. Analysis of the identified fossil ostracods in Lesu: the relationship between entire individuals and valves (left) and the absolute abundance of adults and juveniles of the two species (right).

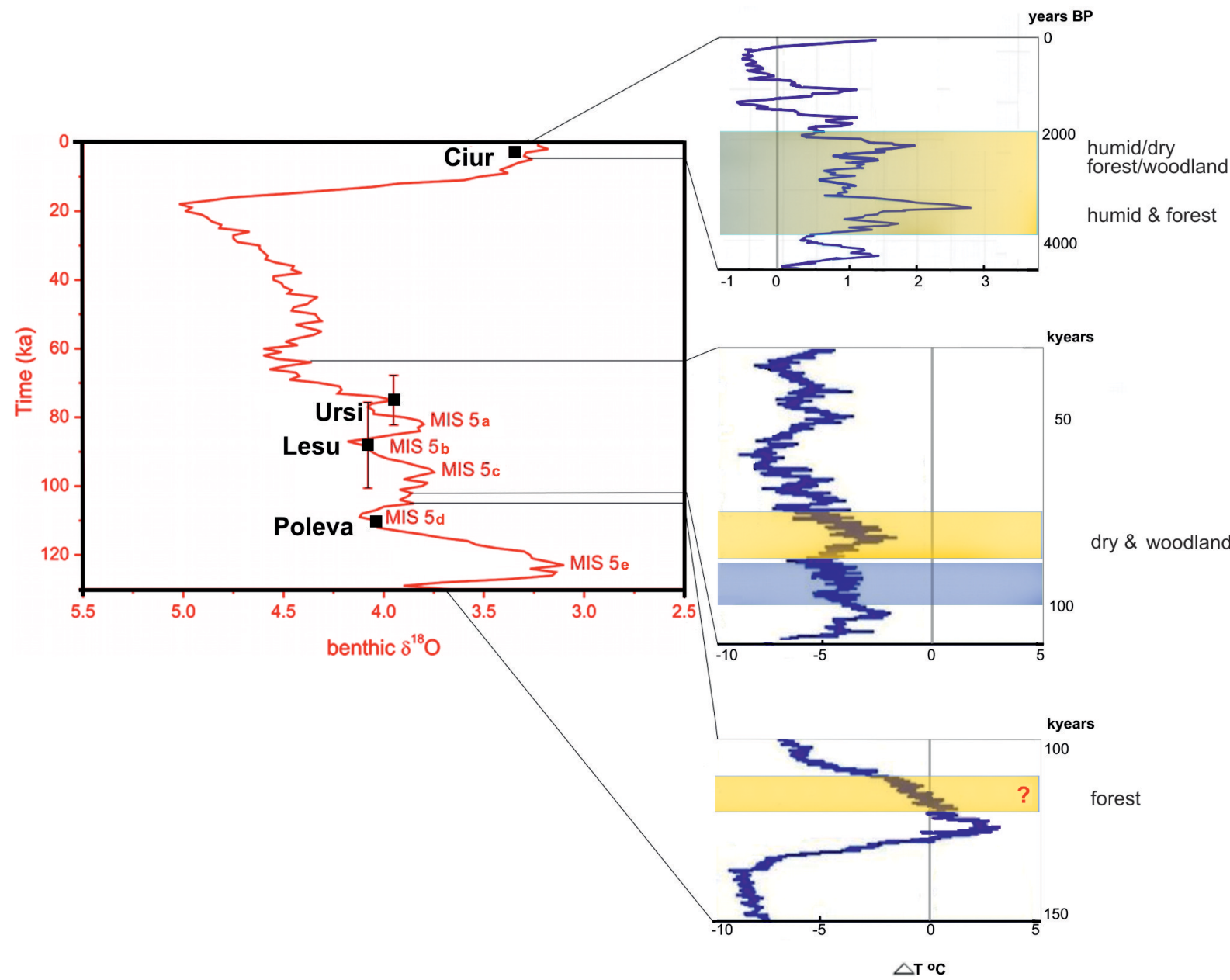

Figure 8. Benthic $\delta^{18} \mathrm{O}$ record with the identified environmental parameters and corresponding temperature variation range during the last $130 \mathrm{ka}$ (benthic $\delta^{18} \mathrm{O}$ curve and temperatures were taken from Lisiecki and Raymo, 2005 and www.dandebat.dk/eng-klima5.htm): blue $=$ cold; yellow $=$ warm . 
Table 3. Taxa found in cave sediments of Romanian caves with the corresponding stages and surface vegetation and/or environments.

\begin{tabular}{|c|c|c|c|c|c|}
\hline \multirow[t]{2}{*}{ Stage } & \multicolumn{4}{|c|}{ TAXA } & \multirow[t]{2}{*}{ Environment } \\
\hline & Ursi & Ciur & Lesu & Poleva & \\
\hline SubAtlantic & & $\begin{array}{l}\text { Oppiella sp. Dissorhina } \\
\text { ornata } \\
\text { Cyclocypris sp. } \\
\text { Hypogeoppia } \mathrm{sp} . \\
\text { Quadroppia } \mathrm{sp} . \\
\text { Alona guttata }\end{array}$ & & & $\begin{array}{l}\text { open habitats } \\
\text { moist } \\
\text { forest/grassland } \\
\text { warm, dense } \\
\text { vegetation }\end{array}$ \\
\hline MIS 3-MIS 5a & Zygoribatula frisiae & & & & arid habitats with trees \\
\hline MIS 5b & & & $\begin{array}{l}\text { Fabaeformiscandona } \\
\text { latens } \\
\text { Cavernocypris } \\
\text { subterranea }\end{array}$ & & $\begin{array}{l}\text { cold waters } \\
\text { colder waters }\end{array}$ \\
\hline Eemian & & & & Hypogeoppia sp. & $\begin{array}{l}\text { moist } \\
\text { forest/grassland }\end{array}$ \\
\hline
\end{tabular}

vegetation at surface was similar during the sediment deposition in both caves (i.e. during the Late Holocene and Eemian, respectively). All identified fossil elements are describing a situation similar to the present, of a sub-Mediterranean forest, with dry and wet elements. This comes into agreement with the assigned Eemian age, an interstadial that is considered to closely resemble the current climate. The beginning of the Eemian is identified in the vegetational sequence by a simultaneous drop in steppic elements and a rise in Eurosiberian and Mediterranean trees (Shackleton et al., 2003). It is also interesting that the same species was identified in sediment stacks from caves located in different topoclimatic regions of the Carpathians, corresponding to different, yet similarly warm major climatic epochs.

\section{Conclusions}

Although invertebrate fossils from cave sediments cannot be designated as an ideal biological proxy, as shown by Elias (2007), the study of fossil invertebrates in cave sediments from the four Carpathian caves indicates their potential as environmental indicators (Table 3 ) for:

i. rapid pluviometric and/or hydrological oscillations along relatively short periods during the Subatlantic and the Late Pleistocene, sometimes accompanied by flooding, as suggested in Ciur by the alternation of terrestrial and aquatic species;

ii. rapid changes of the vegetation/temperature at the surface, with the alternance of forests and more open habitats as in Ciur, or with short cold episodes during a stadial as in the case of Lesu;

iii. deposition of sediments in caves during both warm (Ursi) and cold (Lesu) stages of the Late Pleistocene, with no apparent relationship to the altitudinal position of the cave, which points to the importance of local conditions;

iv. the different hydraulic regimes indicated by the presence of mites during slow flow or stagnant water, and the presence of cladocerans and ostracods during faster flow.

Two of the most abundant fauna representatives, ostracods and mites, were identified in caves from both Carpathians and Dinarids (Moldovan et al., 2011). While ostracods are more often used in paleoenvironmental research, only a few authors advocated the use of mites in such studies (e.g. Solhøy and Solhøy, 2000; Moldovan et al., 2011). Owing to their hard cover (exoskeleton, valves), the preservation of both groups is generally good even in pre-Holocene cave sediments and both are systematically diversified, with various ecological requirements to allow for paleoclimatic or paleoenvironmental assessments.

The presence of common species, such as Hypogeoppia sp., both at different periods and different Carpathian locations (Ciur and Poleva), suggests similar surface ecosystems and points on the need for a regional vs. local approach. The identification of similar taxa in a larger region, such as the Carpathians, and at different periods also emphasize the possible designation of some species as regional proxies for vegetation across a larger timescale.

\section{Perspectives}

Caves sediments and their invertebrates may often be older than many other continental deposits, and are usually found in a relatively good state of preservation. The oldest cave invertebrate fossils found so far date from Carboniferous (Plotnick et al., 2009) and Middle Pliocene (Moldovan et al., 2011; Miko et al., 2012, 2013). Some of the clastic sediments 
cover long time intervals, thus potentially archiving valuable continuum history of the environment and karst evolution at the surface. Caves are numerous in one area and at all latitudes and many have sediments that may include invertebrate species and provide paleoenvironmental information to complement or cross-validate other paleoclimatic records, at least at regional scale.

The greatest potential of the cave sediments in paleoenvironmental studies is given by the fact that multiple proxies can be extracted from them even if, in this case, the multiproxy approach is rather a theoretical than statistical inference. To counterbalance the low density of fossil invertebrates in caves' clastic sediments there are few rules that may enhance the probability of findings: (a) sedimentary profiles should be long enough to have been deposited in different climatic situations; (b) sediments should be fine-grained, from silty-sandy to clay, the best to preserve the fossil invertebrates, owing to the anoxic conditions that block the development of microorganisms involved in biodegradation; (c) the sediments should have been deposited by fluviatile flow with surface origin or subterranean lakes fed by streams with surface origin since most taxa we found were of surface origin.

Author contributions. O. T. Moldovan designed the research and performed the sampling. C. Panaiotu and R. D. Roban performed the sedimentological and rockmagnetic measurements. P. Frenzel and L. Miko identified the ostracods and mites, respectively. All authors contributed to data interpretation. O. T. Moldovan and S. Constantin wrote the manuscript.

Acknowledgements. We are grateful to Ioana Meleg and Laura Epure for sorting the material in the laboratory, to Dan Danielopol, Karina Battes and L’ubomír Kováč for the identification of the ostracods and cladoceran from Ciur, and the collembolan from Poleva, respectively, and to Alida Timar-Gabor and Valentina Anechitei for the OSL datings. We thank the two anonymous reviewers and the editor for their useful comments. This research was funded through the KARSTHIVES Project "Climate archives in karst", CNCS - UEFISCDI Grant PCCE_ID 31/2010 for sampling and analysis, and the EEA Financial Mecanism 2009-2014 under the project CAVEMONITOR (contract no. 17SEE/2014) for interpretation of results.

Edited by: A. Shemesh

\section{References}

Adamiec, G. and Aitken, M.: Dose rate conversion factors: update, Ancient TL, 16, 37-50, 1998.

Bloemendal, J., Lamb, B., and King, J.: Paleoenvironmental implications of rock-magnetic properties of late Quaternary sediment cores from the eastern Equatorial Atlantic, Paleoceanography, 3, 61-87, 1988 .
Bosák, P., Ford, D. C., Głazek, J., and Horáček, I. (eds.): Paleokarst. A Systematic and Regional Review, Elsevier-Academia, Amsterdam-Praha, 1989.

Bosák, P., Pruner, P., and Kadlec, J.: Magnetostratigraphy of cave sediments: application and limits, Stud. Geophys. Geod., 47, 301-330, 2003.

Buggle, B., Hambach, U., Müller, K., Zöller, L., Marković, S. B., and Glaser, B.: Iron mineralogical proxies and Quaternary climate change in SE-European loess-paleosol sequences, Catena, 117, 4-22, 2014.

Constantin, S.: Quaternary paleoclimate evolutions based on speleothem studies from Banat and Mehedinti Mountains, Romania (Unpublished PhD thesis, original in Romanian), Bucuresti University, Bucuresti, 2003.

Constantin, S., Bojar, A.-V., Lauritzen, S. E., and Lundberg, J.: Holocene and Late Pleistocene climate in the sub-Mediterranean continental environment: A speleothem record from Poleva Cave (Southern Carpathians, Romania), Palaeogeogr. Palaeoclim. Palaeoecol., 243, 322-338, 2007.

Constantin, S., Robu, M., Munteanu, C.-M., Petculescu, A., Vlaicu, M., Mirea, I., Kenesz, M., Drăgusin, V., Hoffman, D., Anechitei, V., Timar-Gabor, A., Roban, R.-D., and Panaiotu, C. G.: Reconstructing the evolution of cave systems as a key to understanding the taphonomy of fossil accumulations: The case of Urşilor Cave (Western Carpathians, Romania), Quat. Int., 339/340, 2540, 2014.

Dunlop, D. J. and Özdemir, Ö.: Rock Magnetism: Fundamentals and Frontiers, Cambridge University Press, Cambridge, UK, 1997.

Elias, S. A.: Encyclopedia of Quaternary Science, edited by: Elias, S. A., Elsevier, 2007.

Ellwood, B. B., Harrold, F. B., Benoist, S. L., Straus, L. G., Morales, M. G., Petruso, K., Bicho, N. F., Zilhão, J., and Soler, N.: Paleoclimate and intersite correlations from Late Pleistocene/Holocene cave sites: results from Southern Europe, Geoarchaeol., 16, 33-463, 2001.

Epure, L., Meleg, I. N., Munteanu, C. M., Roban, R. D., and Moldovan, O. T.: Bacterial and Fungal Diversity of Quaternary Cave Sediment Deposits, Geomicrobiol. J., 31, 116-127, 2014.

Epure, L., Muntean, V, Constantin, S., and Moldovan, O.T.: Ecophysiological groups of bacteria from cave sediments as potential indicators of paleoclimate, Quat. Int., in press, doi:10.1016/j.quaint.2015.04.016, 2016.

Evans, M. E. and Heller, F.: Environmental Magnetism. Principles and Applications of Enviromagnetics, Academic Press, Amsterdam, 2003.

Feurdean, A., Liakka, J., Vanniere, B., and Marinova, E.: 12,000Years of fire regime drivers in the lowlands of Transylvania (Central-Eastern Europe): a data-model approach, Quat. Sci. Rev., 81, 48-61, 2013.

Folk, R. L. and Ward, W. C.: Brazos River bar: a study in the significance of grain size parameters, J. Sed. Petrol., 27, 3-26, 1957.

Ford, D. and Williams, P.: Karst Hydrogeology and Geomorphology, Wiley, Chichester, 2007.

Haouchar, D., Haile, J., McDowell, M. C., Murray, D. C., White, N. E., Allcock, R. J. N., Phillips, M. J., Prideaux, G. J., and Bunce, M.: Thorough assessment of DNA preservation from fossil bone and sediments excavated from a late Pleistocene-Holocene cave 
deposit on Kangaroo Island, South Australia, Quat. Sci. Rev., 84, 56-64, 2014.

Herold, N., Yin, Q. Z., Karami, M. P., and Berger, A.: Modelling the climatic diversity of the warm interglacials, Quat. Sci. Rev., 56, 126-141, 2012.

Lauritzen, S.-E. and Onac, B. P.: Isotopic stratigraphy of a Last Interglacial stalagmite from north-western Romania: correlation with the deep-sea record and northern-latitude speleothem, J. Caves Karst Stud., 61, 22-30, 1999.

Lisiecki, L. E. and Raymo, M. E.: A Pliocene-Pleistocene stack of 57 globally distributed benthic $\delta^{18} \mathrm{O}$ records, Paleoceanography, 20, PA1003, doi:10.1029/2004PA001071, 2005.

Lotter, A. F., Birks, H. J. B., Hofmann, W., and Marchetto, A.: Modern diatom, cladocera, chironomid, and chrysophyte cyst assemblages as quantitative indicators for the reconstruction of past environmental conditions in the Alps. I Climate, J. Paleolimnol., 18, 395-420, 1997.

Maher, B. A., Karloukovski, V. V., and Mutch, T. J.: High-field remanence properties of synthetic and natural submicrometre haematites and goethites: significance for environmental contexts, Earth Planet. Sci. Lett., 226, 491-505, 2004.

Meisch, C.: Freshwater Ostracoda of Western and Central Europe, Spektrum Akademischer Verlag GmbH, Heidelberg, Berlin, 2000.

Miko, L., Mourek, J., Meleg, I. N., and Moldovan, O. T.: Oribatid mite fossils from Quaternary and pre-Quaternary sediments in Slovenian caves. I. Two new genera and two new species of the family Oppiidae from the Early Pleistocene, Acta Musei Nationalis Pragae, B, 68, 23-34, 2012.

Miko, L., Mourek, J., Meleg, I. N., and Moldovan, O. T.: Oribatid mite fossils from pre-Quaternary sediments in Slovenian caves II. Amiracarus pliocennatus n.gen., n.sp. (Microzetidae) from Pliocene, with comments on the other species of the genus, Zootaxa, 3670, 557-578, 2013.

Moldovan, O. T., Mihevc, A., Miko, L., Constantin, S., Meleg, I. N., Petculescu, A., and Bosák, P.: Invertebrate fossils from cave sediments: a new proxy for pre-Quaternary paleoenvironments, Biogeosciences, 8, 1825-1837, 2011.

Murray, A. S., and Wintle, A. G.: The single aliquot regenerative dose protocol: potentials for improvement in reliability, Radiat. Measur., 37, 377-381, 2003.

Necula, C., Panaiotu, C., Heslop, D., and Dimofte, D.: Climatic control of magnetic granulometry in the Mircea Vodă loess/paleosol sequence (Dobrogea, Romania), Quat. Int., 293, 5-14, 2013.

Norton, R. A. and Palmer, S. C.: The Acari: Reproduction, Development and Life-History Strategies, edited by: Schuster, R. and Murphy, P. W., Chapman and Hall, London, 1991.

Nováková, K., van Hardenbroek, M., and van der Knaap, W. O.: Response of subfossil Cladocera in Gerzensee (Swiss Plateau) to early Late Glacial environmental change, Palaeogeogr. Palaeoclimatol. Palaeoecol., 391, 84-89, 2013.

Plotnick, R. E., Kenig, F., Scott, A. C., Glasspool, I. J., Eble, C. F., and Lang W. J.: Pennsylvanian paleokarst and cave fi lls from northern Illinois, USA: A window into late Carboniferous environments and landscapes, Palaios, 24, 627-637, 2009.

Plotnick, R. E., Kenig, F., and Scott, A. C.: Strata and Time: Probing the Gaps in Our Understanding, edited by: Smith, D. G., Bailey, R. J., Burgess, P. M., and Fraser, A. J., Geological Society, London, Special Publications, 2015.
Polk, J. S., van Beynen, P. E., and Reeder, P. P.: Late Holocene environmental reconstruction using cave sediments from Belize, Quat. Res., 68, 53-63, 2007.

Reuther, A. U., Urdea, P., Geiger, C., Ivy-Ochs, S., Niller, H.-P., Kubik, P. W., and Hein, K.: Late Pleistocene glacial chronology of the Pietrele valley, Retezat mountains, Southern Carpathians constrained by ${ }^{10} \mathrm{Be}$ exposure ages and pedological investigations, Quat. Int., 164/165, 151-169, 2007.

Rusu, T.: Pe urmele apelor subterane. Carstul din Munţii Pădurea Craiului, Editura Dacia, Cluj-Napoca, Romania, 1988.

Rusu, T. and Racoviţă, G.: Peştera Urşilor de la Chişcău, Ocrotirea Naturii şi a Mediului Înconjurător, 25, 57-71, 1981.

Sasowsky, I.: Clastic sediments in caves - imperfect recorders of processes in karst, Acta Carsol., 36, 143-149, 2007.

Sasowsky, I. D. and Mylroie, J. (Eds): Studies of Cave Sediments.Physical and Chemical Records of Paleoclimate, Kluwer Academic/Plenum Publishers, New York, 2004.

Schwarcz, H. P.: in Handbook of Isotope Geochemistry, edited by: Fritz, P. and Fontes, J., Elsevier, Amsterdam, 1986.

Seniczak, S., Bukowski, G., Seniczak, A., and Bukowska H.: The soil Oribatida (Acari) of the ecotones between the Scots pine forest and lakes in the National Park Bory Tucholskie, Biol. Lett., 43, 221-225, 2006.

Shackleton, N. J., Sánchez-Goñi, M. F., Pailler, D., and Lancelot, Y.: Marine Isotope Substage 5e and the Eemian Interglacial, Global Planet. Change, 36, 151-155, 2003.

Siepel, H. and Dimmers, W.: Some mossmites new for the Netherlands (Acari: Oribatida), Nederlandse faunistische mededelingen, 34, 41-44, 2010.

Shepherd, U. L., Brantley, S. L., and Tarleton, C. A.: Species richness and abundance patterns of microarthropods on cryptobiotic crusts in a pinon-juniper habitat: a call for greater knowledge, J. Arid Environ., 52, 349-360, 2002.

Solhøy, I. and Solhøy, T.: The fossil oribatid mite fauna (Acari: Oribatida) in late glacial and early Holocene sediments in Krakeneslake, western Norway, J. Paleolimnol., 23, 35-47, 2000.

Stevens, T., Marković, S. B., Zech, M., Hambach, U., and Sümegi, P.: Dust deposition and climate in the Carpathian Basin over an independently dated last glacialinterglacial cycle, Quat. Sci. Rev., 30, 662-681, 2011.

Stuart, A. J. and Lister, A. M.: Extinction chronology of the cave lion Panthera spelaea, Quat. Sci. Rev., 30, 2329-2340, 2011.

Subías, L. S. and Rodríguez, P.: Los ópidos (Acari, Oribatida) de los sabinares albares españoles, VII. Géneros Hypogeoppia, Oppiella y Lauroppia, Miscellània Zoològica, 11, 105-111, 1987.

Szeroczyñska, K. and Sarmaja-Korjonen, K.: Atlas of Subfossil Cladocera from Central and Northern Europe, Friends of the Lower Vistula Society, 2007.

Taylor, A. R. and Wolters, V.: Responses of oribatid mite communities to summer drought: The influence of litter type and quality, Soil Biol. Biochem., 37, 2117-2130, 2005.

Wauthy, G. and Ducarme, X.: Description of Hypogeoppia belgicae, a new species of cave mite (Acari, Oribatida), and comments on some characters, Belg. J. Zool, 136, 203-218, 2006.

Webb, D., Robu, M., Moldovan, O., Constantin, S., Tomus, B., and Neag, I.: Ancient human footprints in Ciur-Izbuc Cave, Romania, Am. J. Phys. Anthropol., 155, 128-135, 2014.

Willerslev, E., Hansen, A. J., Binladen, J., Brand, T. B., Thomas, M., Gilbert, P., Shapiro, B., Bunce, M., Wiuf, C., Gilichinsky, 
D. A., and Cooper, A.: Diverse plant and animal genetic records from Holocene and Pleistocene sediments, Science, 300, 791795, 2003.

Wintle, A. G. and Murray, A. S.: A review of quartz optically stimulated luminescence characteristics and their relevance in singlealiquot regeneration dating protocols, Radiat Measur., 41, 369$391,2006$.
Worm, H. U.: On the superparamagnetic-stable single domain transition for magnetite, and frequency dependence of susceptibility, Geophys. J. Int., 133, 201-206, 1998.

Zupan Hajna, N., Mihevc, A., Pruner, P., and Bosák, P.: Paleomagnetism and Magnetostratigraphy of Karst Sediments in Slovenia, Carsologica, 8, Založba ZRC, Ljubljana, 266 pp., 2008. 